\title{
PEMILIHAN STRATEGI BISNIS PEMBENIHAN UDANG VANAME DENGAN METODE INTERNAL-EXTERNAL MATRIX
}

\author{
Marcus Remiasa $^{1^{*}}$, Terry Sugiharto ${ }^{2}$ \\ ${ }^{1,2}$ Fakultas Bisnis dan Ekonomi, Universitas Kristen Petra, Surabaya \\ Email: ${ }^{1}$ markus@petra.ac.id; ${ }^{2}$ terrysugiharto12@gmail.com \\ *Penulis korespondensi
}

\begin{abstract}
Abstrak
Penelitian ini bertujuan untuk merumuskan strategi bisnis pembenihan udang vaname dengan metode Internal External Matrix. Jenis penelitian yang digunakan adalah kualitatif deskriptif. Data dikumpulkan melalui observasi lapangan dan wawancara. Hasil penelitian menunjukkan bahwa posisi strategi perusahaan berada pada kuadran IV mengarah pada strategi grow and build yang terdiri dari strategi intensive dan strategi integrative. Strategi intensive dengan melakukan strategi penetrasi pasar dan stratgei pengembangan pasar sedangkan strategi integrative dengan melakukan strategi integrasi ke depan.
\end{abstract}

Kata kunci: Internal external matrix, strategi bisnis, pembenihan udang vaname.

\begin{abstract}
This study aims to know the application of the Internal-External Matrix to formulate a business strategy for litopenaeus vannamei hatchery. The type of research used is descriptive qualitative. Data was collected through field observation and interviews. The results showed that the strategy position of the company is in quadrant IV led to a grow and build strategy consisting of intensive strategies or integrative strategies. Intensive strategy by implementing market penetration strategies and market development strategies otherwise integrative strategies by carrying out the integration strategy in the future.
\end{abstract}

Keywords: Internal external matrix, bussines strategy, Litopenaeus vannamei hatchery.

\section{PENDAHULUAN}

Wilayah Indonesia yang luas ini memiliki kekayaan sumber daya pesisir dan lautan yang melimpah. Salah satu sumberdaya kelautannya adalah udang. Perusahaan yang menangkap potensi usaha ini adalah PT Semar Emas yang berlokasi Kabupaten Situbondo, Jawa Timur, bergerak dalam usaha pembenihan udang vaname. Perusahan ini merupakan perusahaan keluarga yang didirikan oleh Iwan Sugiharto dan Mega Hutomo pada tahun 2008 dengan visi, "Menjadi perusahaan pembudidaya udang nomor satu di Asia serta berkontribusi untuk mensejahterakan masyarakat". Melalui usaha dan kerja keras selama 10 tahun terakhir, perusahaan mengalami peningkatan permintaan yang signifikan. Penjualan bibit udang vaname di tahun ke-5 dapat mencapai 280.000.000 ton (naik 9,803\%) pada tahun 2012, dan penjualan di tahun ke-10 mencapai 283.000 .000 ton (naik 2,909\%) pada tahun 2017 (lihat Tabel 1)

Keberhasilan usaha perusahaan, tidak lepas dari berbagai faktor pendukung. Faktor demografis, dimana lokasi produksi bibit udang vaname berada di perairan Situbondo dekat dengan sumber mata air sendiri yang berkualitas baik sehingga menunjang efisiensi pembiakan dengan dukungan cuaca yang sangat mendukung. Lokasi pembiakan berada di jalan utama sehingga memudahkan pelanggan untuk menemukan lokasi dan melancarkan transportasi pengiriman produk. Induk udang vaname yang digunakan adalah induk unggulan F1 yang didatangkan langsung dari Hawai.

Tabel 1. Volume Penjualan bibit udang vaname PT Semar Emas Tahun 2008-2018

\begin{tabular}{ccc}
\hline Tahun & Penjualan & Kenaikan (\%) \\
\hline 2008 & 198.000 .000 & - \\
2009 & 215.000 .000 & $8.585 \%$ \\
2010 & 230.000 .000 & $6.976 \%$ \\
2011 & 255.000 .000 & $10,869 \%$ \\
2012 & 280.000 .000 & $9.803 \%$ \\
2013 & 272.000 .000 & $-2,857 \%$ \\
2014 & 281.000 .000 & $3,309 \%$ \\
2015 & 277.000 .000 & $-1,423 \%$ \\
2016 & 275.000 .000 & $-0,722 \%$ \\
2017 & 283.000 .000 & $2,909 \%$ \\
2018 & 279.000 .000 & $-1,413 \%$ \\
\hline
\end{tabular}

Sumber: Data Internal PT Semar Emas, 2019

Jenis indukan ini lebih tahan terhadap penyakit dibandingkan dengan jenis udang lain, pertumbuhan 
sangat cepat dalam budidaya, dan mempunyai daya tahan/adaptasi yang tinggi terhadap kondisi lingkungan. Induk unggulan diperlukan untuk menghasilkan bibit udang vaname yang selanjutnya digunakan oleh petambak budidaya udang vaname.

Dukungan lainnya diperoleh perusahaan adalah dari karyawan yang mahir dalam teknik pembibitan udang vaname. Karyawan berjumlah 20 orang dengan rata-rata pengalaman kerja lebih dari 10 tahun. Perusahaan juga menerapkan teknologi modern antara lain; penggunaan alat produksi dan sarana pembenihan, dan alat pemeriksa PH air, serta alat-alat teknologi penunjang produksi lainnya.

Pemasaran hasil produksi benih udang vaname dilakukan dari mulut ke mulut kepada konsumen/ petambak yang menjangkau sebagian pulau-pulau besar di wilayah Indonesia, antara lain Jawa, Bali, NTB, Sulawesi, dan Kalimantan. Pola manajemen yang diterapkan masih bersifat tradisional, tidak ada uraian/spesifikasi pekerjaan untuk menetapkan status seorang pekerja dalam proses produksi. Sulistiyani dan Rosidah (2003,p. 19) mengemukakan bahwa model tradisional tidak terlepas dari dampak teori birokrasi dimana untuk mengatasi ketidakefisienan dalam perusahaan, maka perusahaan disarankan untuk membuat kriteria pegawai yang jelas, spesialisasi pegawai, kontrol yang kuat, dan penempatan pegawai berdasarkan keahlian.

Setiap perusahaan harus siap menghadapai berbagai faktor eksternal yang dapat mengancam kelangsungan bisnis termasuk bisnis pembibitan udang vaname. Ketidakstabilan kondisi ekonomi di Indonesia pada April 2017 hingga Maret 2018 (lihat gambar 1), dimana nilai tukar rupiah terhadap dolar dari $\mathrm{Rp}$. 13.350 sampai hampir mencapai Rp. 13.800 mempengaruhi kinerja perusahaan. Induk udang vaname diimpor dari Hawai dan dibayar dalam dolar menyebabkan perubahan yang cukup signifikan dalam biaya produksi. Ancaman lain yang dihadapi oleh perusahaan datang dari para kompetitor. Meskipun bahan baku mahal namun karena udang vaname adalah primadona dalam komoditi ekspor Indonesia, maka bisnis ini tetap menarik bagi para pengusaha baru khususnya di wilayah Situbondo.

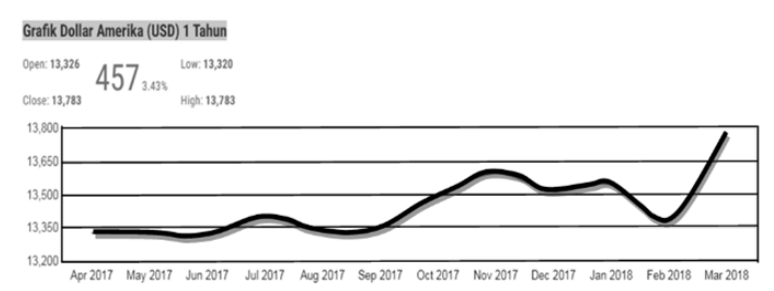

Gambar 1. Grafik Dollar Amerika

Sumber: seputarforex.com
Adanya kebijakan pemerintah yang mendorong peningkatan ekspor udang vaname menarik minat para petambak yang pada akhirnya meningkatkan permintaan terhadap bibit udang vaname. Kondisi ini menguntungkan perusahaan, namun juga menarik minat bagi para pengusaha lain. Pesaing-pesaing baru yang muncul di wilayah Situbondo adalah PT Dewa Ndaru dan PT Dewi Windun. Kedua pesaing adalah perusahaan terbuka atau sudah go-public yang sudah menerapkan pola manajemen modern serta memiliki rantai bisnis yang lebih panjang pada sektor yang sama. Pesaing melakukan pengembangan berupa perluasan jenis produk dan memiliki rantai usaha dari pembenihan udang vaname sampai proses pembesaran udang vaname.

Perusahaan perlu melakukan perencanaan strategis untuk menghadapi berbagai perubahan yang berdampak pada perusahaan. Tahap pertama dalam proses manajemen strategi adalah perumusan strategi (David: 2012). Dalam tahap ini pihak manajemen mengembangkan visi dan misi, mengidentifikasi faktor internal dan eksternal, penetapan tujuan jangka panjang, pencarian strategi-strategi alternative dan pemilihan strategi untuk mencapai tujuan yang telah ditetapkan oleh perusahaan. Kajian ini dimaksudkan untuk merumuskan strategi bisnis pembenihan udang vaname pada PT. Semar Emas dengan metode Internal-External Matrix.

\section{TINJAUAN PUSTAKA}

\section{Perusahaan Keluarga}

Perusahaan keluarga adalah salah satu bentuk usaha yang mengikutsertakan anggota keluarga, baik dalam kepemilikan maupun dalam menjalankan usaha. Susanto (2007) mendeskripsikan ada dua jenis bisnis keluarga yaitu, Family Owned Enterprises (FOE), yaitu perusahaan yang dimiliki oleh keluarga tetapi dikelola oleh eksekutif profesional yang berasal dari luar lingkaran keluarga, dan Family Business Enterprises (FBE), yaitu perusahaan yang dimiliki dan dikelola oleh keluarga pendirinya.

\section{Manajemen Strategis}

Manajemen strategis didefinisikan sebagai seni dan pengetahuan dalam merumuskan, mengimplementasikan, serta mengevaluasi keputusan-keputusan lintas-fungsional yang memampukan sebuah organisasi mencapai tujuannya. Istilah manajemen strategis memiliki sinonim dengan istilah perencanaan strategis, David (2012). 
Menurut David (2012), proses manajemen strategi terdiri atas tiga tahap: perumusan strategi, penerapan strategi, dan penilaian strategi. Perumusan strategi mencakup pengembangan visi dan misi, identifikasi peluang dan ancaman eksternal suatu organisasi, kesadaran akan kekuatan dan kelemahan internal, penetapan tujuan jangka panjang, pencarian strategi-strategi alternatif dan pemilihan strategi tertentu untuk mencapai tujuan.

\section{Visi dan Misi, serta Tujuan Perusahaan}

Pernyataan sebuah visi dan misi yang jelas dibutuhkan sebelum strategi-strategi alternatif dapat dirumuskan dan diterapkan. Menurut Rarick dan Vitton (1995), perusahaan dengan pernyataan misi formal memiliki pengembalian atas ekuitas pemegang saham dua kali lebih besar dibandingkan perusahaan tanpa pernyataan misi (dalam David, 2012). Lebih lanjut Bart dan Baetz (1998) mengemukakan bahwa terdapat tautan positif antara pernyataan misi dan kinerja organisasi (dalam David, 2012).

\section{Identifikasi Peluang dan Ancaman (Analisa Eksternal)}

Analisa eksternal adalah untuk mengembangkan sebuah daftar terbatas dari peluang yang dapat menguntungkan sebuah perusahaan dan ancaman yang harus dihindarinya. Analisa Eksternal bertujuan mengidentifikasi variabel-variabel penting yang menawarkan respons berupa tindakan.

David (2012) menjabarkan kekuatan-kekuatan analisa eksternal utama dapat dibagi menjadi lima kategori luas: (1) kekuatan ekonomi; (2) kekuatan sosial, budaya, demografis, dan lingkungan; (3) kekuatan politik, pemerintahan, dan hukum; (4) kekuatan teknologi; dan (5) kekuatan kompetitif. Tautan antara kekuatan-kekuatan tersebut dengan organisasi secara signifikan memengaruhi semua produk, jasa, pasar, dan organisasi di dunia. David (2012) menjabarkan penjelasan mengenai faktor-faktor eksternal yaitu:

- Kekuatan Ekonomi

Faktor ekonomi memiliki dampak langsung terhadap daya tarik potensial dari beragam strategi.

- Kekuatan Sosial, Budaya, Demografis, dan Lingkungan Perubahan sosial, budaya, demografis, dan lingkungan.

Memiliki dampak yang besar atas hampir semua produk, jasa, pasar dan konsumen. Organisasiorganisasi kecil, besar, laba, dan nirlaba di semua industri dikejutkan dan ditantang oleh peluang dan ancaman yang muncul dari perubahan dalam variabel sosial, budaya, demografis, dan lingkungan.

- Kekuatan Politik, Pemerintahan, dan Hukum Pemerintah baik pusat maupun daerah merupakan pembuat regulasi, deregulasi, penyubsidi, pemberi kerja, dan konsumen utama organisasi. Faktorfaktor politik, pemerintahan, dan hukum, karenanya, dapat merepresentasikan peluang atau ancaman utama baik bagi organisasi kecil maupun besar.

- Kekuatan Teknologi

Perubahan dan penemuan teknologi yang revolusioner memiliki dampak terhadap organisasi. Internet mengubah hakikat terdalam dari peluang dan ancaman dengan mengubah siklus hidup produk, meningkatkan kecepatan distribusi, menciptakan produk dan jasa baru menghapuskan batasan-batasan pasar geografis tradisional, dan mengubah perimbangan historis antara standardisasi produk dan fleksibilitas.

- Kekuatan Kompetitif

Salah satu bagian penting dari audit eksternal adalah mengidentifikasi perusahaan pesaing dan menentukan kekuatan, kelemahan, kapabilitas, peluang, ancaman, tujuan, dan strategi. Variabel lain yang digunakan mencakup pangsa pasar, keluasan produk saingan, ekonomi dunia, afiliasi asing, keuntungan pemilik, daya saing harga, kemajuan teknologi, pergeseran populasi, tingkat suku bunga, dan pengurangan polusi.

\section{Identifikasi Kekuatan dan Kelemahan (Analisis Internal)}

Analisis Internal adalah mengidentifikasi aktivitas terkontrol suatu organisasi yang mampu dijalankan dengan sangat baik atau buruk. Mereka muncul dalam manajemen, pemasaran, keuangan/akuntansi, produksi/operasi, penelitian dan pengembangan, dan aktivitas sistem informasi manajemen suatu bisnis.

Pandangan Berbasis Sumber Daya memperoleh popularitas pada tahun 1990-an dan terus berlanjut sampai sekarang. Pendekatan Pandangan Berbasis Sumber Daya (Resource Based View RBV) terhadap keunggulan kompetitif meyakini bahwa sumber daya internal lebih penting bagi perusahaan daripada berbagai faktor eksternal dalam upaya untuk meraih serta mempertahankan keunggulan kompetitif. Para penganut pandangan RBV percaya bahwa kinerja organisasional akan sangat ditentukan oleh beragam sumber daya internal yang dapat dikelompokkan ke dalam tiga kategori luas: sumber daya fisik, sumber daya manusia, dan sumber daya organisasional. Teori RBV berpendapat bahwa sumber dayalah yang sesungguhnya 
membantu perusahaan menangkap peluang dan menetralkan ancaman (David, 2012, p. 17).

\section{Internal External Matrix (IE-Matrix)}

External Factors Evaluation (EFE) dan Internal Factors Evaluation (IFE) matrix dapat dipergunakan untuk menentukan posisi strategi dan arah strategi yang dilakukan oleh perusahan. EFE dan IFE matrix dibuat setelah melakukan analisa internal dan eksternal. Dari analisa internal dan eksternal, masing-masing faktor diberi bobot dan nilai urutan oleh pihak manajemen perusahaan. Dari bobot dan nilai tersebut diketahui besarnya dampak lingkungan internal dan eksternal. Setelah jumlah EFE dan IFE-nya diketahui selanjutnya dibuat IE-Matrix untuk mengetahui posisi perusahaan berada pada sel keberapa dan arah strategi apa yang perlu dilakukan.

Internal-eksternal matrix terdiri dari 9 sel dan terbagi atas 2 dimensi, yaitu untuk total score tertimbang untuk IFE terletak pada $\mathrm{X}$-axis dan total score tertimbang untuk EFE terletak pada Y-absis (lihat gambar 2.). Selain itu Internal-External Matrix juga terbagi dalam 3 daerah yang memiliki implikasi strategi yang berbeda-beda. Untuk sel I, II, IV strategi yang dipilih adalah strategi "Grow dan Build", terdiri atas strategi intensive (penetrasi pasar, pengembangan pasar, pengembangan produk) atau strategi integrative (integrasi ke belakang, ke depan, dan horizontal). Untuk sel III, V, VII strategi yang dipilih adalah strategi "Hold dan Maintain), terdiri atas strategi penetrasi pasar dan pengembangan produk. Dan untuk sel VI, VIII, IX strategi yang dipilih adalah strategi "Harvest atau Divest".

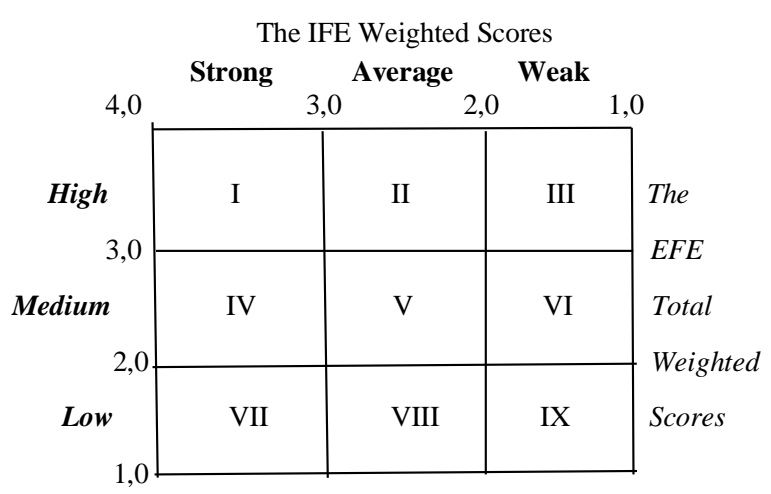

Gambar 2. The Internal-External (IE) Matrix Sumber: David (2012)

Langkah-langkah dalam perumusan strategi mencakup pengembangan visi misi dan tujuan, mengidentifikasi faktor internal (kekuatan dan kelemahan) dan faktor eksternal (peluang dan ancaman) yang mampu dijalankan oleh PT Semar Emas secara relatif bila dibandingkan dengan kompetitor, kemudian penetapan tujuan jangka panjang, dan pencarian strategistrategi alternatif dan pemilihan strategi tertentu untuk mencapai tujuan perusahaan dengan menggunakan metode Internal External Matrix (IE-Matrix).

\section{METODE PENELITIAN}

Penelitian ini adalah penelitian kualitatif deskriptif yang menggambarkan kondisi apa adanya, begitupula dalam memperoleh data yang lebih menekankan makna pada hasilnya. Desain penelitian berupa studi kasus pada PT Semar Emas yang berlokasi di Jalan Raya Kali Anget, KM 151, Besuki, Kabupaten Situbondo, Jawa Timur.

Data Penelitian ini menggunakan data primer yang diperoleh dari survey atau field research dan wawancara mendalam (in-dept interviewing) kepada informan atau narasumber berjumlah 4 orang, terdiri dari; komisaris perusahaan, direktur utama perusahaan, kepala teknisi departemen produksi dan sekertaris PT Semar Emas. Selain wawancara, data juga diperoleh dengan cara membagikan kuesioner kepada para narasumber. Data yang dikumpulkan meliputi visi misi, faktor eksternal dan internal dengan menggunakan pertanyaan pengarah sebagai berikut:

1. Visi dan Misi

Pertanyaan pengarah terkait visi dan misi adalah: sejarah berdirinya perusahaan, visi dan misi perusahaan, dan tujuan dari pendirian perusahaan.

\section{Faktor Eksternal}

Pertanyaan pengarah faktor eksternal diperlukan untuk mengembangkan sebuah daftar terbatas dari peluang yang dapat menguntungkan perusahaan dan ancaman yang harus di hindarinya meliputi: Apakah kestabilan ekonomi dan peraturan pemerintah memberi dampak bagi bisnis pembenihan udang vaname?; Alat-alat teknologi apa saja yang sangat dibutuhkan untuk melakukan pembenihan udang vaname?; Bagaimana kondisi lingkungan penduduk sekitar perusahaan?; Mengapa memilih lokasi Situbondo sebagai lokasi pembenihan?; Apa yang menjadi keunggulan dalam perusahaan anda dibandingkan dengan kompetitor lainya?

3. Faktor Internal

Pertanyaan pengarah faktor internal diperlukan untuk mengembangkan daftar terbatas yang dapat mengidentifikasi kekuatan dan kelemahan dari masing-masing fungsi bisnis yang ada di perusahaan. Pertanyaan yang relevan antara lain: Hal-hal apa saja yang berkaitan erat dengan proses produksi perusahaan?; Apakah fasilitas, perlengkapan, 
mesin dan kantor anda dalam kondisi yang baik?; Bagaimana perusahaan melakukan pemasaran produk?; Bagaimana kondisi sumberdaya manusia yang dimiliki sekarang?; Bagaimana perusahaan menetapkan suatu standar dalam melakukan perekrutan karyawan?; Bagaimana sumber pendanaan perusahaan?; Apakah bersumber dari dana pribadi?; Bagaimana kondisi keuangan perusahaan?; dan Apakah memiliki modal kerja yang mencukupi?

Berdasarkan jawaban narasumber atas pertanyaan di atas, kemudian disusun kuesioner yang berisi pernyataan tentang faktor ekstemal dan internal yang akan digunakan untuk memvalidasi jawaban narasumber. Tiap pernyataan diberi skor dan urutan nilai/ rating dengan teknis sebagai berikut:

1. Pengisian skor dan nilai urutan untuk faktor internal dan faktor eksternal.

Skor dimulai dari 1 (tidak penting) sampai dengan skor 9 (sangat penting). Nilai urutan untuk internal faktor berdasarkan pada respon perusahaan terhadap faktor internal. Nilai urutan mulai dai 1 (major weakness), 2 (minor weakness), 3 (minor strength), dan 4 (major strength). Sedangkan eksternal faktor nilai urutan mulai dari 1 (poor), 2 (average), 3 (above average), dan 4 (superior).

2. Perhitungan IFE-Matrix dan EFE-Matrix

Setelah pemberian skor oleh para nara sumber kemudian dilakukan tabulasi skor rata-rata guna menetapkan bobot (weight) untuk internal faktor dan eksternal faktor. Dengan cara yang sama setelah pemberian urutan nilai (rating) oleh para nara sumber kemudian dilakukan tabulasi rating rata-rata guna menetapkan rating untuk internal faktor dan eksternal faktor. Hasil tabulasi skor dan tabulasi rating tersebut digunakan untuk menentukan Internal Factors Evaluation Matrix (IFE-Matrix) dan External Factors Evaluation Matrix (EFE-Matrix). Dari IFE-matrix dan EFEmatrix ini kemudian ditetapkan posisi dan strategi perusahaan yang diperlihatkan pada metode Internal-External Matrix (IE-Matrix).

Untuk memastikan validitas data, dilakukan pengujian dengan triangulasi sebagai pengecekan data dari berbagai sumber dengan berbagai cara, dan berbagai waktu (Sugiyono, 2009, p. 464). Triangulasi data dilakukan dengan mengecek data kepada sumber yang sama menggunakan teknik yang berbeda. Data diperoleh dengan wawancara, lalu dicek dengan observasi, dokumentasi dan kuesioner.

\section{HASIL PENELITIAN DAN PEMBAHASAN}

PT. Semar Emas berdiri pada tahun 1990 di Jalan Raya Kalianget, Besuki, Situbondo, Km 151-152, Jawa Timur. Didirikan oleh Iwan Sugiharto dan Mega Hutomo sebagai pengelola, dan masing-masing memegang jabatan Direktur utama dan Komisaris Perusahaan, sekaligus sebagai pemegang $100 \%$ saham perusahaan. Begitupula dengan posisi penting perusahaan dipegang oleh anggota keluarga. Perusahaan ini dikatagorikan sebagai Family Business Enterprises (FBE), yaitu perusahaan yang dimiliki dan dikelola oleh keluarga pendirinya. Jadi baik pengelolaan dan kepemilikan dipegang oleh orang yang sama, yaitu keluarga. Awal mulanya perusahan ini merupakan perusahaan yang bergerak pada pembenihan udang (pemeliharaan naupli-post larva) yang memproduksi benih udang windu (Penaeus monodon).

Berdasaarkan perkembangan dan kebutuhan pasar ekspor, perusahaan memutuskan untuk beralih ke pembenihan udang vaname, sehingga tahun 2008 beralih pada bisnis pembenihan udang vaname (Litopenaeus vannamei) yang induknya didatangkan langsung dari Hawai, yang biasa disebut induk F1 dan berkualitas tinggi dengan selalu berkomitmen mengutamakan kualitas benih yang dihasilkan.

\section{Visi, Misi dan Tujuan PT Semar Emas}

Visi, misi dan tujuan PT Semar Emas memberikan gambaran yang jelas tentang arah masa depan dan perilaku organisasi. Perusahaan ini telah memiliki visi, misi dan tujuan yang baik. Visinya adalah "Menjadi perusahaan pembudidaya udang nomor satu di Asia serta berkontribusi untuk mensejahterakan masyarakat". Memiliki 4 Misi, yaitu; 1) Menghasilkan benih unggulan dengan mengunakan mendatangkan induk unggulan dari hawai. 2) Meningkatkan jumlah skala produksi, dan memperbesar skala perusahaan untuk menjaga keberlanjutan budidaya. 3) Membuka lapangan kerja baru untuk mengurangi angka kemiskinan. 4) Mendukung pemenuhan standar budidaya yang baik untuk meningkatkan akses pasar nasional dan global. Perusahan ini mempunyai 2 Tujuan, yaitu; 1) Meningkatkan kesejahteraan masyarakat. 2) Mewujudkan kelestarian sumberdaya budidaya udang.

\section{Analisis Faktor Eksternal dan Faktor Internal}

Berdasarkan hasil wawancara pada keempat nara sumber dari perusahaan, maka diperoleh data mengenai evaluasi faktor eksternal dan evaluasi faktor internal. 
Analisis faktor eksternal digunakan untuk menggambarkan peluang (opportunities) dan ancaman (threats) sedangkan analisa faktor internal digunakan untuk menggambarkan kekuatan (strengths) dan kelemahan (weaknesses) yang sedang dihadapi oleh perusahaan. Faktor yang digunakan dalam analisis faktor eksternal dan internal adalah:

Peluang (Opportunities)

- Meningkatnya jumlah petambak udang vaname di seluruh Indonesia. Dalam radius $10 \mathrm{KM}$ dari lokasi perusahaan, terdapat setidaknya lima petambak.

- Kebijakan pemerintah yang mendorong peningkatan ekspor udang vaname.

- Menurunnya permintaan udang windu. Penambak udang beralih menggunakan bibit udang vaname.

\section{Ancaman (Threats)}

- Munculnya kompetitor baru dalam bidang penambakan bibit udang vaname - dengan melihat bagusnya peluang untuk berbisnis di dalam industri pertambakan bibit udang vaname, munculnya kompetitor baru dapat menjadi ancaman bagi perusahaan.

- Kondisi ekonomi yang tidak stabil, membawa dampak pada harga induk udang vaname karena harus didatangkan secara impor. Kondisi ekonomi ini berhubungan langsung dengan nilai tukar mata uang negara terhadap dolar.

\section{Kekuatan (Strengths)}

- Lokasi produksi bibit udang, perusahaan memiliki lokasi pembiakan dekat dengan sumber mata air sendiri dan berkualitas baik sehingga menunjang efisiensi pembiakan. Selain itu, lokasi pembiakan berada di jalan utama sehingga memudahkan pelanggan untuk menemukan lokasi dan juga memudahkan transportasi pengiriman produk,

- Induk unggulan, benih udang yang dimiliki oleh perusahaan merupakan induk unggulan F1 yang langsung berasal dari Hawai.

- Memiliki fasilitas yang modern, perusahaan menggunakan alat produksi dan sarana pembenihan yang modern dan intensif serta menggunakan alat filterisasi.

- Kualitas sumberdaya manusia, karyawan sudah berpengalaman dalam bidang pembenihan udang vaname dengan lama bekerja rata-rata 10 tahun.

- Kerja sama yang baik dengan supplier induk, apabila terjadi perubahan selera konsumen, perusahaan tidak sulit untuk memenuhi kebutuhan benih sesuai selera konsumen.

Kelemahan (Weaknesses)

- Manajemen Perusahaan, masih menggunakan sistem manual.

- Manajemen pemasaran, strategi pemasaran yang digunakan hanya melalui Word of Mouth (mulut ke mulut)

\section{Metode Internal-External Matrix (IE-Matrix)}

Pendekatan dengan metode IE-Matrix ini untuk menentukan posisi dan strategi perusahaan, yang diawali dengan analisis faktor eksternal dan internal perusahan dibandingkan para pesaingnya. Kemudian menghitung bobot dan rating, menghitung EFE-Matix dan IFE-Matrix, dan menentukan posisi dan strategi perusahaan dengan menggunakan IE-Matrix.

\section{Perhitungan Bobot dan Rating Faktor Eksternal dan Faktor Internal}

Sebelum melakukan perhitungan bobot pada faktor eksternal dan faktor internal, para narasumber yang berjumlah 4 orang mengisi score pada kuesioner penelitian. Score dimulai dari 1 (tidak penting) sampai 9 (sangat penting). Setelah itu menghitung bobotnya. Hasil perhitungan bobot rata-rata faktor eksternal dan faktor internal seperti pada tabel 2 dan pada tabel 3.

Sama seperti perhitungan bobot di atas, sebelum melakukan perhitungan rating pada faktor eksternal dan faktor internal, para narasumber yang berjumlah 4 orang mengisi nilai urutan/rating pada kuesioner penelitian. Untuk faktor internal, nilai urutan/rating dimulai dari 1 (major weakness), 2 (minor weakness), 3 (minor strength) dan 4 (major strenght). Sedangkan untuk faktor eksternal nilai urutan mulai dari 1 (poor), 2 (average), 3 (above average), dan 4 (superior). (David,2012). Setelah itu menghitung rating. Hasil perhitungan rating rata-rata faktor eksternal dan faktor internal seperti pada tabel 4 dan pada tabel 5 .

\section{Perhitungan IFE-Matrix dan EFE-Matrix}

Hasil tabulasi bobot (score) rata-rata dan tabulasi rating rata-rata pada tabel 2 sampai tabel 5 digunakan untuk menentukan External Factors Evaluation Matrix (EFE-Matrix) dan Internal Factors Evaluation Matrix (IFE-Matrix). Hasilnya masing-masing dapat dilihat pada tabel 6 dan tabel 7. Dari EFE-Matrix dan IFE-Matrix ini kemudian ditetapkan posisi dan strategi perusahaan yang diperlihatkan pada metode InternalExternal Matrix (IE-Matrix) seperti tampak pada gambar 3.

Dari hasil External Factor Evaluation Matrix (EFE-Matrix), perusahaan mendapatkan perolehan total nilai terbobot 2.967 (tabel 6), dengan nilai yang diperoleh berada di atas 2.5, yang berarti perusahaan sudah memiliki strategi yang efektif dalam merespon faktor peluang dan ancaman yang dihadapi, sehingga dapat terus bertahan di antara persaingan usaha pembenihan udang vaname. 
Tabel 2. Tabulasi Bobot Rata-Rata Faktor Eksternal

\begin{tabular}{lccccccc}
\hline \multicolumn{1}{c}{ Faktor Eksternal } & \multicolumn{4}{c}{ Narasumber } & \multirow{2}{*}{ Jumlah } & \multirow{2}{*}{ Rata - rata } \\
\cline { 2 - 5 } & $\mathbf{1}$ & $\mathbf{2}$ & $\mathbf{3}$ & $\mathbf{4}$ & & & \\
Peluang & & & & & & & \\
Meningkatnya jumlah petambak & 0.081 & 0.228 & 0.064 & 0.349 & 0.722 & 0.180 \\
Kebijakan pemerintah & 0.351 & 0.037 & 0.057 & 0.055 & 0.5 & 0.125 \\
Menurunya permintaan udang windu & 0.149 & 0.26 & 0.258 & 0.046 & 0.713 & 0.179 \\
Ancaman & & & & & & \\
Munculnya kompetitor baru & 0.082 & 0.118 & 0.231 & 0.137 & 0.568 & 0.142 \\
Kondisi ekonomi yang tidak stabil & 0.337 & 0.358 & 0.390 & 0.412 & 1.497 & 0.374 \\
\hline Total & & & & & & & 1.000 \\
\hline
\end{tabular}

Tabel 3. Tabulasi Bobot Rata-Rata Faktor Internal

\begin{tabular}{|c|c|c|c|c|c|c|}
\hline \multirow{2}{*}{ Faktor Internal } & \multicolumn{4}{|c|}{ Narasumber } & \multirow{2}{*}{ Jumlah } & \multirow{2}{*}{ Rata - rata } \\
\hline & 1 & 2 & 3 & 4 & & \\
\hline \multicolumn{7}{|l|}{ Kekuatan } \\
\hline Lokasi produksi bibit udang & 0.342 & 0.332 & 0.293 & 0.38 & 1.347 & 0.336 \\
\hline Induk unggulan & 0.179 & 0.259 & 0.166 & 0.268 & 0.872 & 0.218 \\
\hline Memiliki fasilitas modern & 0.126 & 0.101 & 0.145 & 0.059 & 0.431 & 0.108 \\
\hline Kualitas sumberdaya manusia & 0.128 & 0.068 & 0.072 & 0.060 & 0.328 & 0.082 \\
\hline $\begin{array}{l}\text { Kerjasama yang baik dengan supplier induk } \\
\text { Kelemahan }\end{array}$ & 0.138 & 0.126 & 0.149 & 0.159 & 0.572 & 0.143 \\
\hline Manajemen Perusahaan tergolong kuno & 0.031 & 0.036 & 0.043 & 0.030 & 0.14 & 0.035 \\
\hline Manajemen pemasaran yang tradisional & 0.056 & 0.078 & 0.133 & 0.045 & 0.312 & 0.078 \\
\hline Total & & & & & & 1.000 \\
\hline
\end{tabular}

Tabel 4. Tabulasi Rating Rata-Rata Faktor Eksternal

\begin{tabular}{|c|c|c|c|c|c|c|}
\hline \multirow{2}{*}{ Faktor Eksternal } & \multicolumn{4}{|c|}{ Narasumber } & \multirow{2}{*}{ Jumlah } & \multirow{2}{*}{ Rata - rata } \\
\hline & 1 & 2 & 3 & 4 & & \\
\hline \multicolumn{7}{|l|}{ Peluang } \\
\hline Meningkatnya jumlah petambak & 3 & 4 & 2 & 3 & 12 & 3 \\
\hline Kebijakan pemerintah & 2 & 3 & 2 & 3 & 10 & 2.5 \\
\hline Menurunya permintaan udang windu & 3 & 4 & 3 & 3 & 13 & 3.25 \\
\hline \multicolumn{7}{|l|}{ Ancaman } \\
\hline Munculnya kompetitor baru & 4 & 3 & 3 & 4 & 14 & 3.5 \\
\hline Kondisi ekonomi yang tidak stabil & 3 & 3 & 2 & 3 & 11 & 2.75 \\
\hline
\end{tabular}

Tabel 5. Tabulasi Rating Rata-Rata Faktor Internal

\begin{tabular}{|c|c|c|c|c|c|c|}
\hline \multirow{2}{*}{ Faktor Internal } & \multicolumn{4}{|c|}{ Narasumber } & \multirow{2}{*}{ Jumlah } & \multirow{2}{*}{ Rata - rata } \\
\hline & 1 & 2 & 3 & 4 & & \\
\hline \multicolumn{7}{|l|}{ Kekuatan } \\
\hline Lokasi produksi bibit udang & 4 & 4 & 4 & 4 & 16 & 4 \\
\hline Induk unggulan & 4 & 3 & 3 & 4 & 14 & 3.5 \\
\hline Memilik fasilitas yang modern & 3 & 3 & 3 & 3 & 12 & 3 \\
\hline Kualitas sumberdaya manusia & 4 & 4 & 3 & 3 & 14 & 3.5 \\
\hline Kerjasama yang baik dengan supplier induk & 3 & 4 & 3 & 3 & 13 & 3.25 \\
\hline \multicolumn{7}{|l|}{ Kelemahan } \\
\hline Manajemen Perusahaan yang tergolong kuno & 2 & 3 & 4 & 3 & 12 & 3 \\
\hline Manajemen pemasaran yang tradisional & 2 & 3 & 2 & 3 & 10 & 2.5 \\
\hline
\end{tabular}


Tabel 6. External Factors Evaluation Matrix (EFE-Matrix)

\begin{tabular}{lccc}
\hline Faktor Eksternal & Bobot & Rating & $\begin{array}{c}\text { Nilai } \\
\text { Terbobot }\end{array}$ \\
\hline $\begin{array}{l}\text { Peluang } \\
\text { Meningkatnya jumlah } \\
\text { petambak }\end{array}$ & 0.180 & 3 & 0.54 \\
$\begin{array}{l}\text { Kebijakan pemerintah } \\
\text { Merosotnya produksi }\end{array}$ & 0.125 & 2.5 & 0.312 \\
$\begin{array}{l}\text { udang windu } \\
\begin{array}{l}\text { Ancaman } \\
\text { Kompetitor baru }\end{array}\end{array}$ & 0.179 & 3.25 & 0.581 \\
$\begin{array}{l}\text { Kondisi ekonomi yang } \\
\text { tidak stabil }\end{array}$ & 0.142 & 3.5 & 0.497 \\
\hline Total & 0.374 & 2.75 & 1.028 \\
\hline
\end{tabular}

Dari hasil Internal Factor Evaluation Matrix (IFE-Matrix), perusahaan mendapatkan perolehan total nilai terbobot 3,482 (tabel 7) dengan nilai yang diperoleh berada di atas 2.5 , yang berarti perusahaan dapat menggunakan kekuatan dan menanggulangi kelemahan yang dimiliki dengan sangat baik sehingga mampu menghadapi persaingan usaha pembenihan udang vaname.

Tabel 7. Internal Factors Evaluation Matrix (IFE-Matrix)

\begin{tabular}{lccc}
\hline Faktor internal & Bobot & Rating & $\begin{array}{c}\text { Nilai } \\
\text { Terbobot }\end{array}$ \\
\hline $\begin{array}{l}\text { Kekuatan } \\
\text { Lokasi produksi bibit } \\
\text { udang }\end{array}$ & 0.336 & 4 & 1.344 \\
$\begin{array}{l}\text { Induk unggulan } \\
\text { Memiliki fasilitas yang }\end{array}$ & 0.218 & 3.5 & 0.763 \\
$\quad$ modern & 0.108 & 3 & 0.324 \\
$\begin{array}{l}\text { Kualitas sumberdaya } \\
\text { manusia }\end{array}$ & 0.082 & 3.5 & 0.287 \\
$\begin{array}{l}\text { Kerjasama yang baik } \\
\quad \text { dengan supplier }\end{array}$ & 0.143 & 3.25 & 0.464 \\
$\quad$ induk \\
$\begin{array}{l}\text { Kelemahan } \\
\text { Manajemen } \\
\quad \begin{array}{l}\text { Perusahaan } \\
\text { tergolong kuno }\end{array}\end{array}$ & 0.035 & 3 & 0.105 \\
$\begin{array}{l}\text { Manajemen pemasaran } \\
\text { yang tradisional }\end{array}$ & 0.078 & 2.5 & 0.195 \\
\hline Total & 1.000 & & 3.482 \\
\hline
\end{tabular}

\section{Posisi strategi PT. Semar Emas}

Untuk menentukan arah dan sasaran strategi untuk mencapai tujuan, terlebih dahulu menentukan posisi perusahaan. Dari hasil perhitungan EFE-Matrix (Tabel 6) dihasilkan besaran pengaruh lingkungan eksternal perusahaan (besar total skor tertimbang untuk EFE) sebesar 2,967. Sedangkan IFE-Matrix (Tabel 7) dihasilkan besaran pengaruh lingkungan internal (besar total skor tertimbang untuk IFE) sebesar 3,482. Berdasarkan hasil penilaian tersebut dipasangkan pada Internal-External Matrix (IE-Matrix), seperti pada gambar 3 (lihat lingkaran kecil) menunjukan bahwa perusahaan ini berada pada kuadran IV. Posisi ini menunjukan bahwa PT Semar Emas mengarah pada strategi grow and build.

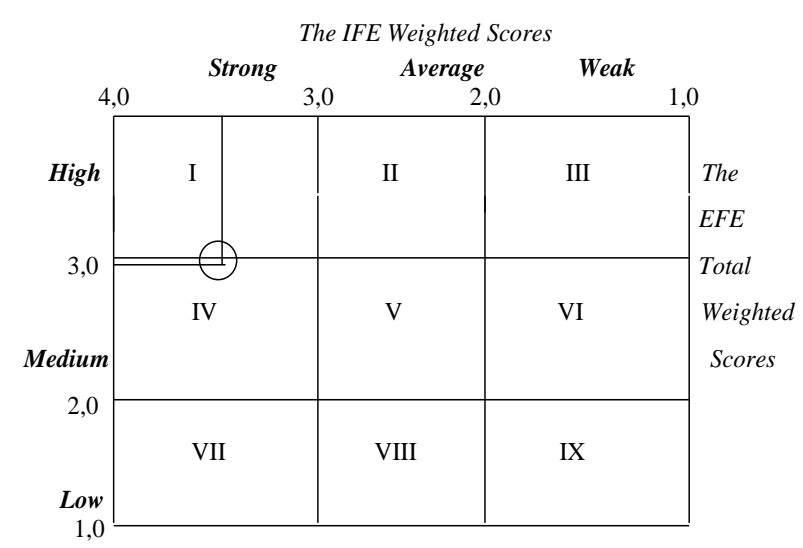

Gambar 3. The Internal-External Matrix (IE-Matrix) Sumber: David (2012), hasil diolah

\section{Strategi Alternatif PT. Semar Emas}

Dengan mengetahui posisi perusahaan, maka dapat disusun strategi untuk menentukan ke arah mana dan apa yang ingin dicapai dalam tujuan perusahaan. Menurut David (2012) bila perusahaan berada pada posisi IV maka strategi yang dipilih adalah stategi grow dan build, dimana terdapat 2 alternatif strategi yaitu strategi Intensive atau strategi integrative. Selanjutnya dikatakan bahwa yang tergolong srategi intensive adalah strategi penetrasi pasar, pengembangan pasar, dan pengembangan produk. Sedangkan strategi integrative terdiri dari strategi integrasi ke belakang, integrasi ke depan dan integrasi horizontal.

\section{Perumusan Strategi Bisnis PT. Semar Emas}

Dalam merumuskan strategi bisnis perusahaan dengan pendekatan IE-Matrix seperti tampak pada gambar 3 menunjukan posisi strategi dan arah strategi perusahaan. Bila dilihat hasil perhitungan evaluasi faktor internal dan eksternal menunjukan bahwa besaran total skor tertimbang untuk IFE sebesar 3,482 lebih besar dari EFE sebesar 2,967 dan berada di atas 2.5 , yang berarti secara internal perusahaan dapat menggunakan kekuatan dan menanggulangi kelemahan dengan sangat baik sehingga mampu menghadapi persaingan usaha pembenihan udang vaname. Secara internal perusahaan memiliki sumber daya yang kuat dalam menghadapi ancaman dan meraih peluang. 
Sejalan dengan pandangan Berbasis Sumber Daya (Resource Based View RBV) terhadap keunggulan kompetitif meyakini bahwa sumber daya internal lebih penting bagi perusahaan daripada berbagai faktor eksternal untuk meraih serta mempertahankan keunggulan kompetitif. Sumber daya internal dimaksud adalah sumber daya fisik, sumber daya manusia, dan sumber daya organisasional. Perusahaan telah memiliki 3 sumber daya internal dimaksud. Pertama, sumber daya fisik dengan memiliki lokasi produksi bibit udang dengan bobot 0,336 dan rating 4 (lihat tabel 7) tertinggi dari seluruh faktor yang dimiliki oleh perusahaan. Lokasi produksi bibit udang memiliki sumber mata air sendiri dan berkualitas baik sehingga menunjang efisiensi pembiakan. Kedua, kualitas sumber daya manusia memiliki kompetensi dan berpengalaman dalam hal pembenihan udang dengan tingkat turnover yang rendah dan rata-rata sudah bekerja selama 10 tahun. Ketiga, sumber daya organisasional $100 \%$ saham adalah milik sendiri dimana pengelolaan dan kepemilikan dikelola oleh keluarga. Teori RBV berpendapat bahwa sumber dayalah yang sesungguhnya membantu perusahaan menangkap peluang dan menetralkan ancaman (David, 2012, p. 17).

Jika dikaitkan dengan visi, misi dan tujuan perusahaan maka perusahaan ini memiliki peluang besar untuk meraihnya. Maka strategi yang sangat mungkin adalah strategi intensif dengan berupaya secara intensif meningkatkan posisi kompetitif perusahaan dengan produk utama yaitu menghasilkan benih udang vaname. Strategi intensive memiliki 3 strategi, yaitu strategi penetrasi pasar, pengembangan pasar dan pengembangan produk. Dari ketiga strategi ini, pengembangan produk belum memungkinkan karena produk utamanya adalah penghasil benih udang vaname yang selanjutnya dibudidayakan oleh petambak untuk menghasilkan udang vaname. Sehingga strategi yang relevan dengan kondisi saat ini adalah penerapan strategi penetrasi pasar dan pengembangan pasar.

Sedangkan Strategi integratif yang sangat mungkin untuk diterapkan adalah strategi integrasi ke depan dalam upaya mengendalikan jalur distribusi. Strategi integrasi ke belakang tidak dapat diterapkan oleh perusahaan karena tidak mungkin untuk memperoleh kepemilikan atas perusahaan pemasok yang menyuplai induk unggulan udang vaname F1 dari Hawai. Begitupula dengan strategi integrasi horizontal tidak mudah untuk memperoleh kepemilikan atas perusahaan pesaing yang sebagian besar sudah go-public, sementara PT Semar Emas dikatagorikan sebagai Family Business Enterprises (FBE), yakni perusahaan yang dimiliki dan dikelola oleh keluarga sendiri.

Berdasarkan uraian/penjelasan di atas dan dengan mempertimbangkan pada pencapaian visi, misi dan tujuan, maka perusahaan dapat menerapkan strategi penetrasi pasar, strategi pengembangan pasar dan strategi integrasi ke depan.

\section{Strategi Penetrasi Pasar}

Strategi penetrasi pasar adalah upaya meningkatkan penjualan produk yang ada ke pasar sekarang dengan menguatkan aspek pemasaran yang makin efektif dan variatif agar lebih tepat sasaran. Strategi ini tepat untuk dilakukan karena manajemen pemasaran yang tradisional dari perusahaan memiliki nilai terbobot yang rendah sebesar 0,078 dan rating 2,5 (Tabel 7). Hal tersebut terjadi karena perusahaan menggunakan sistem pemasaran tradisional dari mulut ke mulut dengan pelangan sehingga membuat sistem pemasaran tidak maksimal.

Langkah perbaikan manajemen pemasaran harus dilakukan dalam mempertahankan pasar saat ini adalah dengan terus menjaga dan mempertahankan segmen pasar, target pasar dan posisi pasar yang telah ada. Perusahaan dapat meningkatkan manajemen pemasaran dengan menguatkan aspek promosi, dengan iklan yang makin efektif dan variatif sesuai dengan target pasar atau mungkin dengan cara pendekatan yang berbeda namun lebih tepat sasaran seperti pemasaran melalui metode online atau berbasis E-commers agar cakupan pemasaran lebih luas serta tidak terbatas oleh relasi yang dimiliki perusahaan saat ini saja. Metode online atau E-commers dapat menjangkau segmentasi pasar, target pasar dan posisi pasar perusahaan saat ini yang secara geografis berada di wilayah Jawa, Bali, Nusa Tenggara Barat (NTB), Sulawesi dan Kalimantan.

\section{Strategi pengembangan pasar}

Pengembangan pasar adalah upaya yang dilakukan untuk membuka di pasar yang baru dengan terus menjual bibit udang vaname ke pasar yang baru. Hal ini sangat mungkin dilakukan karena kebijakan pemerintah yang mendorong peningkatan ekspor udang vaname yang berdampak pada kenaikkan permintaan terhadap bibit udang vaname. Peluang ini memiliki bobot 0,125 dengan nilai rating 2,5 (tabel 6), walau peluang ini masi lebih rendah dari faktor eksternal lainnya. Kesempatan bagi pihak PT Semar Emas untuk memasarkan produk yang ada pada pasar baru sangat mungkin dan terbuka lebar. Bila dilihat dari jaringan distribusi yang dibangun maka baru 5 pulau dari 17.499 pulau di Indonesia yang memiliki potensi wilayah pesisir dan lautan yang menyediakan sumber daya kelautan potensial berupa udang. Sehingga wilayah lain yang belum menjadi target pasar bisa 
menjadi pasar baru (pengembangan pasar), karena mudah dijangkau dan pertumbuhan ekonominya juga baik.

\section{Strategi integrasi ke depan}

Strategi integrasi ke depan adalah strategi yang dijalankan untuk mengendalikan jalur distribusi. Mendirikan sendiri jalur distribusi oleh perusahaan menjadi pilihan yang strategis ke depan dengan posisi dan arah strataegi perusahaan dengan mempertimbangkan peluang yang ada. Peluang tersebut adalah merosotnya produksi udang windu dengan bobot 0,179 dan rating 3,25 tertinggi dari seluruh faktor eksternal yang dimiliki oleh perusahaan, dan meningkatnya jumlah petambak dengan bobot 0,180 dan rating 3 (lihat tabel 6). Peluang ini memungkinkan perusahaan untuk membuka jalur distribusi yang baru dengan membuka lahan/tambak bagi proses pembesaran udang vaname. Memiliki jalur distribusi seperti ini, perusahan memiliki rantai usaha dari pembenihan udang vaname hingga kepada proses budidaya udang vaname.

\section{KESIMPULAN DAN SARAN}

Implementasi pendekatan Internal-External Matrix (IE-Matrix) pada PT Semar Emas menunjukkan bahwa posisi strategi berada pada kuadran IV mengarah pada strategi grow and build yang terdiri dari strategi intensive atau strategi integrative. Strategi intensive dilakukan dengan strategi penetrasi pasar dan stratgei pengembangan pasar sedangkan strategi integrative dilakukan dengan strategi integrasi ke depan.

Berdasarkan posisi strategi dan arah strategi perusahaan yang telah didapatkan, maka PT Semar Emas perlu melakukan perbaikan manajemen perusahaan dengan mengadopsi pola manajemen dan teknologi produksi modern.
Aspek pemasaran juga perlu dibenahi. Perusahaan perlu meningkatkan promosi dan iklan dengan memanfaatkan teknologi internet melalui metode online atau berbasis E-commerce. Dengan mempergencar pemasaran dan dengan cara yang lebih variatif maka perusahaan akan dapat menjangkau segmen pasar yang lebih luas dan tersebar di wilayah Indonesia. Perusahaan juga dapat membuka jalur distribusi dengan membangun lahan/tambak budidaya udang vaname. Dengan demikian perusahaan memiliki rantai usaha dari pembenihan hingga budidaya udang vaname.

\section{DAFTAR REFERENSI}

Creswell, J. W. (2013). Qualitative inquiry \& research design. California: Sage Publications.

David, F. R. (2012). Manajemen strategis konsep (12 ed). (Dono Sunardi, Trans.). Jakarta: Salemba Empat.

David, F. R. (2012). Strategic management concepts and cases. California: Prentice-Hall.

Harisudin, M. (2011). Competitive profile matrix sebagai alat analisis strategi pemasaran produk atau jasa. SEPA 7 (2), 80-84.

Moleong, L. J. 2013. Metode penelitian kualitatif(edisi revisi). Bandung: Remaja Rosdakarya.

Sohel1, S. M., Rahman, A. M. A., \& Uddin, M. A. (2014). Competitive profile matrix (CPM) as a competitors' analysis tool: A theoretical perspective. IJHPD, 3(1), 40-47.

Sugiyono. (2009). Metode penelitian bisnis. Bandung: Alfabeta.

Sulistiyani, A. T. \& Rosidah. (2013). Manajemen sumber daya manusia. Yogyakarta: Graha Ilmu.

Widodo, D.P. (2010). Competitive profile matrix dan mckinsey capacity assessment grid sebagai perangkat analisis manajemen strategis. 